\title{
Use of Sewage Sludge Treated with some Stabilizers in Reducing Nickel Availability in the Soil and Absorption by Plants
}

\author{
Gomah, Hala H. ${ }^{1}$; G.A. Elgharabley ${ }^{1}$; A.G. Haridy ${ }^{2}$ and Amna A.M. Ahmed ${ }^{1}$ \\ ${ }^{1}$ Soil and Water Dept., Faculty of Agriculture, Assiut University \\ ${ }^{2}$ Vegetables Dept., Faculty of Agriculture, Assiut University
}

Received on: $12 / 7 / 2018$

Accepted for publication on: 9/8/2018

Abstract
Sewage sludge was treated with some Ni stabilizers including silica gel (Si), cement by- pass (CB) and iron oxide (FO) to reduce its availability in the soil, and absorption by onion plants (direct effect) in the first season and Jew's mallow plants (residual effect) in the second season. A loamy sand soil was amended only before the first season with sewage sludge treatments including 10 and $20 \% \mathrm{Si}, \mathrm{CB}$ and FO treated sludge as well as $\mathrm{Si}+\mathrm{CB}, \mathrm{Si}+\mathrm{FO}$ and $\mathrm{CB}+\mathrm{FO}$ treated ones.

Sludge treated with $20 \% \mathrm{Si}$ was the best one in reducing Ni effects in the soil and plants, it also increased the length, shoot and bulb fresh weights, shoot and bulb dry weight of onion plants by 17.2, 148.5, 6.99, 127.8 and $159.2 \%$, respectively, compared to the control. However, the untreated sludge application increased the soil extractable Ni from $0.30 \mathrm{mg} / \mathrm{kg}$ in the control to $2.79 \mathrm{mg} / \mathrm{kg}$ after the harvest of onion plants. Amending the soil with sludge treated with FO $+\mathrm{CB}, \mathrm{Si}+\mathrm{CB}$ and $\mathrm{Si}+\mathrm{FO}$ significantly reduced the soil extractable $\mathrm{Ni} 100 \%$ of that amended with untreated sludge after onion harvest. The extractable Ni significantly decreased after Jew's mallow harvest from $0.30,2.79,1.15,3.47$ and $2.52 \mathrm{mg} / \mathrm{kg}$ to $0.00,0.00,0.00,0.52$ and $1.27 \mathrm{mg} / \mathrm{kg}$ with the control, untreated sludge, $10 \% \mathrm{CB}, 20 \% \mathrm{CB}$ and $10 \% \mathrm{FO}$ treatments, respectively.

In the first season (direct effect), sludge amended with $\mathrm{Si}+\mathrm{FO}$ was the best treatment that reduced $\mathrm{Ni}$ content of the shoots and bulbs by 71.6 and $75.6 \%$ compared to the control. Moreover, in the second season (residual effect), sludge amended with $20 \% \mathrm{Si}$ was the best treatment that reduced the Ni content of Jew's mallow plants by $71.8 \%$ and $66.8 \%$ compared to the control.

Keywords: Nickel, sewage sludge, stabilization, heavy metals, residual effect

\section{Introduction}

Sewage sludge (biosolids) represents a good source of nutrients for plant growth due to its high content of nutrients and organic matter. It is also considered as a good soil conditioner that improves the physical, chemical, and biological properties of soil (Alcantara et al., 2009; Angin and Yağanoğlu, 2009). Land application of biosolids materials is a common practice in many countries that allow the reuse of biosolids produced by urban populations (Weggler et al., 2004). Heavy metals that are commonly found in biosolids includelead $(\mathrm{Pb})$, nickel $(\mathrm{Ni})$, cadmium $(\mathrm{Cd})$, chromium $(\mathrm{Cr})$, cupper $(\mathrm{Cu})$, and zinc $(\mathrm{Zn})$. The metal concentration is governed by the nature and the intensity of the industrial activity, as well as the process type employed during the biosolids treatment (Mattigod and Page, 1983). Municipal wastes such as sewage biosolids have been used as an amendment for agricultural 
soils for several years. They are often considered an economically attractive alternative to disposal through landfill and incineration (Diacono and Montemurro 2010). Using sewage sludge as a fertilizer enables cost reductions of nitrogen and phosphorus mineral fertilizers and may improve crop yields in sludge treated fields (Wild and Jones, 1991; Petersen et al., 2003).

The only drawback in the use of sewage sludge on agricultural land is its pollutant load including heavy metals, organic compounds, pharmaceuticals and pathogens. Potentially toxic elements are a general term for a wide range of metalssuch as cadmium, copper, nickel, lead, zinc, mercury and chromium that originate in sewage. Heavy metal pollution represents an important environmental problem due to their toxic effects resulting in serious ecological and health problems. The metals are concentrated in the sludge as a result of their association with settable solids during the primary and secondary treatment processes (Sterritt and Lester, 1980). Research on the land application of sewage sludge has mainly focused on its role in the introduction of heavy metals in the food chain. The regulatory authorities normally accept remediation strategies that center on reducing the metal bioavailability only if the reduced bioavailability is equated with reduced risk, and if the bioavailability reductions are according to be longterm (Martin and Ruby, 2004).

Udeigwe et al. (2011) reported that the immobilization mechanisms of contaminants such as heavy metals could include: 1) Preciptaton as salts,
2) the co-precipitation, 3) the surface precipitation, 4) and the adsorption to mineral surfaces stable complexes. The net negative charge of mineral surfaces increases when a specific adsorption of anions occurs leading to an increase in the retention of metal cations such as $\mathrm{Cd}^{2+}, \mathrm{Cu}^{2+}$ and $\mathrm{Zn}^{2+}$ (Boland et al., 1999).

Nanoparticles of magnetite (an iron oxide mineral) have a unique super paramagnetism and a high surface area (Yuan et al., 2009) which offer more multiple surface sites for adsorption or interaction the iron oxide mineral as (Paljevac et al., 2007) that makean innovative immobilization carrier (Sulek et al., 2010; Xu et al., 2012). Sen et al. (2002) indicated that the higher adsorption of $\mathrm{Ni}^{2+}$ on iron oxides compared to that of $\mathrm{Cu}^{2+}$ is due to the relatively smaller size of $\mathrm{Ni}^{2+}$ ions. In addition, iron oxide minerals are better adsorbents compared tokaolinnes due to the specific adsorption of the metal that occurs on the iron oxides which is induced by the inner - sphere complexation.

Silica gel has a large specific surface area and fast adsorption kinetics (Jiang et al., 2007). It also possesses a highly porous and rigid texture (Repo et al., 2011; Waseem et al., 2011). In addition, silica gel surface consists of inter connected particles forming a three dimensional skeleton. (Fenglian and Wang, 2011).

Cement By-pass is a product of the cement industry. In Assiut cement company, it consists of $11.88 \% \mathrm{SiO}_{2}$, $2.97 \% \mathrm{Al}_{2} \mathrm{O}_{3}, 2.60 \% \mathrm{Fe}_{2} \mathrm{O}_{3}, 47.8 \%$ $\mathrm{CaO}, 0.68 \% \mathrm{MgO}, 12.13 \% \mathrm{SO}_{3}, 2.28$ $\mathrm{Na}_{2} \mathrm{O}, 4.38 \% \quad \mathrm{~K}_{2} \mathrm{O}$ and $4.81 \% \quad \mathrm{Cl}$ (Amin, 2013). Abou-Seeda et al. (2005) reported that the available soil 
$\mathrm{Pb}, \mathrm{Cd}$, and $\mathrm{Ni}$ were decreased by $10-$ $20,30-40$ and $25-30 \%$, respectively, with the application of cement dust. Moreover, treating the sludge with the cement kiln dust reduces the solubility and increases the immobilization of heavy metals in the treated sludge matrix (Emmerich et al., 1982). Kigel et al. (1994) also showed that the application of cement kiln dust stabilized chromium in waste sludge.

Therefore, this study aims to evaluate the $\mathrm{Ni}$ availability and content of onion (direct effect) and Jew's mallow (residual effect) plants grown in a sandy soil amended with sewage sludge treated with some stabilizers (silica gel, cement by-pass and iron oxide).

\section{Materials and Methods \\ 1- Sewage sludge treatments}

Three materials (silica gel "Si", cement by-pass "CB" and ferric oxide "FO") were used as stabilizers in order to reduce $\mathrm{Ni}$ availability from sewage sludge. Samples of sewage sludge were collected from Elmadabigh sewage plant, Assiut, air- dried, ground using a wooden roller and sieved through a huge sieve plate. The fine tested sludge contained $51.7 \%$ organic matter, $6.0 \% \mathrm{~N}, 1.7 \%$ $\mathrm{P}_{2} \mathrm{O}_{5}, 0.6 \%, \mathrm{~K}_{2} \mathrm{O}, 11.2 \% \mathrm{CaO}$ and 6.0 $\% \mathrm{MgO}$. The total heavy metals contents of the sludge were 15285,623 , $335,3.1,249,0.9$ and $58.7 \mathrm{mg} / \mathrm{kg}$ for $\mathrm{Fe}, \mathrm{Zn}, \mathrm{Cu}, \mathrm{Cd}, \mathrm{Pb}, \mathrm{Cr}$ and $\mathrm{Ni}, \mathrm{re}-$ spectively. The fine sewage sludge was treated and thoroughly mixed with each stabilizer material at levels of 10 and $20 \%$. Other treatments were prepared from treating and mixing the sewage sludge with two stabilizer materials, each one at a level of $10 \%$ to produce a total of 9 treatments (Table 1). For three weeks, the treated sewage sludge materials were weighed every day to add the amount of water lost during the sieving and mixed. Then, they were transferred to the lab and air - dried for another week. The nickel content of these treated sludges was extracted using $0.1 \mathrm{M}$ ethylene diamin tetra acetic acid (EDTA) according to Wear and Evans (1968) and then, determined (Table 1).

Table 1. The EDTA-extractable Ni $(\mathrm{mg} / \mathrm{kg})$ in the sludge materials treated with iron oxide (FO), cement-bypass (CB) and silica gel (Si)

\begin{tabular}{|c|c|}
\hline Treatments & EDTA- extractableNi (mg/kg) \\
\hline control & 15.30 \\
\hline FO $10 \%$ & 16.50 \\
\hline FO $20 \%$ & 13.00 \\
\hline CB $10 \%$ & 12.30 \\
\hline CB $20 \%$ & 12.10 \\
\hline Si $10 \%$ & 13.80 \\
\hline Si $20 \%$ & 11.60 \\
\hline FO $10 \%+\mathrm{CB} 10 \%$ & 12.20 \\
\hline FO $10 \%+$ Si $10 \%$ & 14.90 \\
\hline CB $10 \%+$ Si $10 \%$ & 10.90 \\
\hline
\end{tabular}

\section{2- Pot Experiments:}

Pot experiments were conducted in the green house to evaluate the ef- fect of the stabilizer treated sewage sludge on the Ni availability and content of $\mathrm{Ni}$ in onion (Allium Cepa) 
plants (direct effect) and Jew's mallow (Chorcoruis Olitorus) plants (residual effect) grown in the sandy soil. In the first season (October, 2016), onion seedlings were planted in pots filled with $5 \mathrm{~kg}$ of soil amended with the sludge treated with the previous different stabilizer at a level of 20 $\mathrm{t} / \mathrm{fed}$. Therefore, as it was mentioned previously, the soil was amended with 9 treatments of sewage sludge (Table 1). Each treatment was replicated 3 times. The texture of used soil was loamy sand $(13.68 \%$ clay, $4.00 \%$ silt and $84.32 \%$ sand) with $\mathrm{pH}$ of 7.18 , EC (1:5 soil extract) of 3.22 $\mathrm{dsm}^{-1}$ and $\mathrm{CaCO}_{3}$ content of $13.85 \%$. The soil also contained 1.10, 0.60 , $12.25,2.15,7.82$ and $2.54 \mathrm{meqL}^{-1}$ of $\mathrm{Na}^{+}, \mathrm{K}^{+}, \mathrm{Ca}^{2+}, \mathrm{Mg}^{2+}, \mathrm{CO}_{3}{ }^{2+}$ and $\mathrm{Cl}^{-}$, respectively (Jakson, 1973). After 12 weeks the onion plants were harvested and the bulbs were separated from shoots, washed, dried at $70^{\circ} \mathrm{C}$, ground and stored for chemical analysis. On the same pots without any new applications of the treated sewage sludge, 20 seeds of Jew's mallow were planted in July, 2017 to investigate the residual effect of the previous sludge treatments on the availability and content of $\mathrm{Ni}$ in these plants. After 12 weeks, the plants were harvested, washed, air dried, oven dried at $70^{\circ} \mathrm{C}$, ground and stored for chemical analysis. Soil samples were collected after each growing season, thoroughly mixed, air-dried, ground to pass a 2-mm sieve and stored for chemical analysis. Nickel was extracted from the soil using EDTA method according to Wear and
Evans (1968). All plant samples were digested using a mixture of $\mathrm{H}_{2} \mathrm{O}_{2}$, selenium, lithium sulfate and concentrated sulfuric acid (Parkinson and Allen, 1975). Nickel was determined, in both soil and plant digests using Flame Atomic Absorption Spectrophotometer (GBC).

This study was conducted in a simple experiment and the treatments were arranged in a completerandomized design (CRD) with three replications using SAS package version 9.0. The MSTATC 2.10 computer program prepared by Freed (1992) was used to perform the analysis of variance. The obtained data were subjected to statistical analysis of variance according to Gomez and Gomez (1984) and the means of treatments were tested using the least significant difference method (LSD) at $\mathrm{P}=0.05$.

\section{Results and Discussion}

1- Direct effects of treated sludgematerials on some vegetative properties of onion plants (first season):

Compared with the control (the soil without any treatment), the untreated sludge decreased plant length, shootand bulb fresh weight, shoot and bulbs dry weight of onion plants by $12.3,47.8,70.2,33.3$ and $37.0 \%$, respectively (Table 2). This may be due to the toxic effects of heavy metals in sludge according to DeVries and Tiller (1978), significant concentrations of $\mathrm{Cd}, \mathrm{Cu}, \mathrm{Mn}, \mathrm{Ni}, \mathrm{Pb}$ and $\mathrm{Zn}$ were found in the edible parts of lettuce tops and onion bulbs that were grown on soils amended with sewage sludge. 
Website: www.aun.edu.eg/faculty_agriculture/journals_issues_form.php E-mail:ajas@aun.edu.eg

Table 2. Direct effects of sludge treated with cement bypass (CB), ferric oxide (FO) and silica gel $(\mathrm{Si})$ on some vegetative properties of onion plants

\begin{tabular}{|c|c|c|c|c|c|c|c|}
\hline \multirow{2}{*}{ Treatment } & $\begin{array}{c}\text { Plant length } \\
(\mathbf{c m})\end{array}$ & \multicolumn{3}{|c|}{ Fresh weight (g/pot) } & \multicolumn{3}{c|}{ Dry weight (g/pot) } \\
\cline { 3 - 8 } & shoots & Bulb & Total & shoots & Bulb & Total \\
\hline Control & 30.50 & 8.51 & 9.15 & 17.65 & 2.73 & 1.35 & 4.08 \\
\hline Un- Sludge & 26.75 & 4.44 & 2.72 & 7.16 & 1.82 & 0.85 & 2.67 \\
\hline CB 10\% & 25.94 & 3.59 & 4.54 & 8.13 & 0.71 & 0.79 & 1.50 \\
\hline CB 20\% & 29.01 & 5.16 & 6.94 & 12.10 & 1.68 & 1.50 & 3.18 \\
\hline FO 10\% & 20.00 & 2.83 & 1.17 & 3.99 & 1.27 & 0.35 & 1.62 \\
\hline FO 20\% & 23.75 & 4.82 & 4.68 & 9.50 & 3.11 & 2.34 & 5.45 \\
\hline Si 10\% & 31.00 & 10.22 & 6.16 & 16.38 & 3.21 & 1.68 & 4.89 \\
\hline Si 20\% & 35.75 & 21.15 & 9.79 & 30.94 & 6.22 & 3.50 & 9.72 \\
\hline FO+ CB & 32.75 & 11.80 & 9.69 & 21.49 & 3.87 & 1.63 & 5.50 \\
\hline Si + CB & 29.75 & 9.11 & 6.03 & 15.14 & 5.27 & 2.91 & 8.18 \\
\hline Si + FO & 37.88 & 7.02 & 8.20 & 15.22 & 2.28 & 1.88 & 4.16 \\
\hline LSD 0.05 & 1.17 & 0.71 & 0.82 & 0.75 & 0.70 & 0.78 & 1.22 \\
\hline
\end{tabular}

The application of sludge treated with silica gel + iron oxide ( $\mathrm{Si}+\mathrm{FO})$ and $20 \%$ silica gel $(\mathrm{Si})$ significantly increased onion length from $30.50 \mathrm{~cm}$ for the control and from $26.75 \mathrm{~cm}$ for the untreated sludge to $37.88 \mathrm{~cm}$ and $35.75 \mathrm{~cm}$, respectively. The sludge treated with $20 \%$ silica gel was the best treatment, it increased the onion total length, shoot fresh weight, bulb fresh weight, shoot dry weight and bulb dry weight by $17.2,148.5,6.99,127.8$ and $159.2 \%$, respectively, compared to the control. The respective increases were 33.6, 376.4, 259.9, 241.8 and $311.8 \%$, compared to the untreated sludge treatment. The application of sludge treated with iron oxide and cement by-pass $(\mathrm{FO}+\mathrm{CB})$ also significantly increased the plant length, shoot and bulb fresh weights by $22.4,165.8$ and $256.3 \%$, respectively, compared to the untreated sludge.

2- Residual effects of treated sludge materials on some vegetative properties of Jew's mallow plants (second season):

The residual effect of untreated sludge showed the same decrease trend that was indicated for onion plants (direct effect) showed with respect of the length, fresh and dry weights of Jew's mallow plants compared to the control treatment (Table 3).

Table 3. Residual effects of sludge treated with cement by-pass (CB), iron oxide (FO) and silica gel ( $\mathrm{Si}$ ) on some vegetative properties of Jew's mallow plants

\begin{tabular}{|c|c|c|c|}
\hline Treatment & Total Length (cm) & Fresh Weight (g/pot) & Dry Weight (g/pot) \\
\hline Control & 10.0 & 2.74 & 0.26 \\
\hline Un- Sludge & 9.0 & 1.56 & 0.24 \\
\hline CB 10\% & 16.3 & 5.20 & 2.10 \\
\hline CB 20\% & 22.7 & 10.40 & 2.44 \\
\hline FO 10\% & 18.0 & 1.44 & 0.36 \\
\hline FO 20\% & 24.0 & 12.62 & 5.16 \\
\hline Si 10\% & 27.0 & 36.60 & 8.60 \\
\hline Si 20\% & 32.3 & 13.92 & 2.98 \\
\hline FO + CB & 25.3 & 7.64 & 1.64 \\
\hline Si + CB & 31.4 & 9.80 & 2.52 \\
\hline Si + FO & 25.5 & 9.74 & 3.16 \\
\hline LSD 0.05 & 1.4 & 0.49 & 0.06 \\
\hline
\end{tabular}


The respective decreases were $10,43.1$ and $7.7 \%$ for the vegetative properties. The residual effect of untreated sewage sludge also exhibited the same trendrecorded for the direct untreated sewage application but with lower reduction effects on Jew's mallow vegetative properties which it may be attributed to the lower residual contents of heavy metals in the second season. Treating the sludge with any of the investigated materials resulted in significant increases in the plant length, fresh and dry weights except the $20 \%$ FO amended sludge treatment. The plant length reached $32.25 \mathrm{~cm}$ using the sludge treated with $20 \%$ Si resulting in an increase of $222.5 \%$ compared to the control. The level of plant uptake, bioaccumulation and tolerance of plants to heavy metals varies among different crops at different application levels of sewage sludge (Yilmaz, et al., 2012).

3- Direct and residual effects of treated sludge materials on nickel content of onion (first season) and Jew's mallow (second season) plants:

The Ni content of onion shoots and bulbs (first season) and Jew's mallow plants (second season) grown on the soil amended with stabilizer treated sludges are shown in Table (4). In the first season (direct effect), the $\mathrm{Si}+\mathrm{FO}$ treated sludge was the best treatment which reduced the $\mathrm{Ni}$ content of the shoots and bulbs by 71.6 and 75.6 , respectively, compared to the control and by 87.0 and $68.7 \%$, respectively, compared to the untreated sludge. In the second season it was also one of the best treatments in reducing $\mathrm{Ni}$ content of Jew's mallow plants by $60.7 \%$ compared to the control. In addition, in the first season, treating the sludge with 10 and $20 \%$ of FO significantly decreased the $\mathrm{Ni}$ content by 72.2 and $63.2 \%$, respectively, for onion shoots and by 21.3 and $50.2 \%$, respectively, for onion bulbs compared to the untreated sludge.

In the second season, the $\mathrm{Si}+\mathrm{FO}$ treated sludge was the best treatment which significantly reduced the $\mathrm{Ni}$ content of Jew's mallow plants by 71.8 and $60.5 \%$ compared to the control and the untreated sludge, respectively. However, both $20 \% \mathrm{FO}$ and $10 \% \mathrm{Si}$ treated sludges reduced the Ni content of Jew's mallow plants by $56 \%$ compared to the control. Sen et al. (2002) indicated that the higher adsorption of $\mathrm{Ni}^{2+}$ on iron oxides compared to that of $\mathrm{Cu}^{2+}$ is due to the relatively smaller size of $\mathrm{Ni}^{2+}$ ions. In addition, iron oxide minerals are better adsorbents compared to kaolin ones due to the specific adsorption of the metal that occurs on the iron oxides which is induced by the innersphere complexation. The results also showed that Jew's mallow plants could accumulate higher amounts of $\mathrm{Ni}$ in their tissues compared to onion plants. It seems that Jew's mallow plants have the ability to secrete root exudates that may chelate non exchangeable $\mathrm{Ni}$ and transform it into an exchangeable form. More researches should be done on Jew's mallow plants and their ability to absorb and accumulate Ni. 
Table 4. Effect of sludge treated with cement by-pass (CB), iron oxide (FO) and silica gel $(\mathrm{Si})$ on the $\mathrm{Ni}$ content $(\mathrm{me} / \mathrm{kg}$ ) of onion plants (first season) and Jew's mallow plants (second season)

\begin{tabular}{|c|c|c|c|}
\hline \multirow{3}{*}{ Treatment } & \multicolumn{3}{|c|}{ Ni content $(\mathrm{mg} / \mathrm{kg})$} \\
\hline & \multicolumn{2}{|c|}{$\begin{array}{l}\text { Onion plants } \\
\text { (Direct effect) }\end{array}$} & \multirow{2}{*}{$\begin{array}{l}\text { Jew's mallow plants } \\
\text { (Residual effect) }\end{array}$} \\
\hline & Shoots & Bullb & \\
\hline Control & 11.98 & 22.90 & 167.90 \\
\hline Un- Sludge & 26.25 & 17.87 & 120.07 \\
\hline CB 10\% & 18.95 & 14.67 & 291.68 \\
\hline CB 20\% & 25.03 & 19.50 & 111.58 \\
\hline FO 10\% & 7.30 & 14.75 & 86.75 \\
\hline FO 20\% & 9.65 & 8.90 & 73.74 \\
\hline Si $10 \%$ & 14.95 & 18.95 & 73.20 \\
\hline Si $20 \%$ & 26.68 & 17.93 & 89.55 \\
\hline $\mathrm{FO}+\mathrm{CB}$ & 25.98 & 12.90 & 115.40 \\
\hline $\mathbf{S i}+\mathbf{C B}$ & 19.05 & 16.20 & 92.64 \\
\hline $\mathbf{S i}+\mathbf{F O}$ & 3.40 & 5.95 & 47.38 \\
\hline $\operatorname{LSD}_{0.05}$ & 1.12 & 1.03 & 1.71 \\
\hline
\end{tabular}

4- Direct and residual effects of treated sludge materials on EDTA -extractable Ni of the soil:

Table (5) showsthe amounts of EDTA- extractable Ni of the soil after harvesting both of onion (direct effect) and Jew's mallow plants (residual effect). In the first season (direct effect), the soil extractable $\mathrm{Ni}$ increased with applying all sludge treatments (including theuntreated sludge) except with the sludge treated with mixtures of two stabilizing materials which displayed a very high stabilizing effect on the extractable Ni. The application of untreated sludge significantly increased the extractable $\mathrm{Ni}$ of the soil from 0.30 to $2.79 \mathrm{mg} / \mathrm{kg}$ due to the high content of $\mathrm{Ni}$ in the sludge $(58.7 \mathrm{mg} / \mathrm{kg})$. Amending the soil with sludge treated with $\mathrm{FO}+\mathrm{CB}, \mathrm{Si}+\mathrm{CB}$ and $\mathrm{Si}+\mathrm{FO}$ significantly stabilized all amounts of the extractable $\mathrm{Ni}$ in the soil and sludge in the first season resulting in $100 \%$ reduction of the extractable $\mathrm{Ni}$. Gomah, (2015) indicated that treating sewage sludge with silica gel mixedwith ferric oxide or zeolite, each of them at $15 \%$, reduced $100 \%$ of the extractable Ni. Sen et al. (2002) used preliminary kinetic experiments to explain the adsorption of $\mathrm{Ni}^{2+}$ and $\mathrm{Cu}^{2+}$ metal ions on iron oxide and reported that the adsorption a two- step process including: an adsorption of the metal ion on the external surface which rapid followed by slow intraparticle diffusion in the interior parts of the particles.

Although Jew's mallow plants were grown on the soil without any new sludge treatments (residual treatments), the EDTA extractable Ni of the soils lightly increased using $20 \% \mathrm{FO}$ and $10 \% \mathrm{Si}$ treated sludges and markedly increased using 20\% $\mathrm{Si}, \mathrm{FO}+\mathrm{CB}, \mathrm{Si}+\mathrm{CB}$ and $\mathrm{Si}+\mathrm{FO}$ treated ones. One or more reasons can be responsible for these increases including: 1- the root exudates excreted from the Jew's mallow plants may solubilize some of the total $\mathrm{Ni}$ content of the sludge (Gomah and Ez- 
zeldin, 2003), 2- the decomposition of sludge may release more $\mathrm{Ni}$ to the soil and/or 3- the formation of soluble organic Ni complexes that may become more extractable by EDTA. Silica gel has a high surface area (Jiang et al., 2007) withporosity and rigid structure (Fenglian and Wang, 2011; Repo et al., 2011). On the other hand, the extractable Ni of the soil markedly and significantly decreased from $0.30,2.79,1.15,3.47$ and $2.52 \mathrm{me} / \mathrm{kg}$ in the first season to $0.00,0.00,0.00$, 0.52 and $1.27 \mathrm{me} / \mathrm{kg}$ in the second season for the control, untreated sludge, $10 \% \mathrm{CB}, 20 \% \mathrm{CB}$ and $10 \%$ FO sludge treatments, respectively. These results may be attributed to increasing the $\mathrm{Ni}$ fixation of these treatments with time resulting in decreases the extractable Ni or/ and the high Ni absorption by Jew's mallow plants.

Table 5. Effect of sludge treated with cement by-pass (CB), iron oxide (FO) and silica gel on EDTA - extractable $\mathrm{Ni}(\mathrm{me} / \mathrm{kg})$ of the soil after the first andsecond seasons.

\begin{tabular}{|c|c|c|}
\hline \multirow{2}{*}{ Treatment } & \multicolumn{2}{|c|}{ Ni content ( me/kg ) } \\
\cline { 2 - 3 } & $\begin{array}{c}\text { First Season } \\
\text { (Direct effect }\end{array}$ & $\begin{array}{c}\text { Second Season } \\
\text { (Residual effect) }\end{array}$ \\
\hline Control & 0.30 & 0.00 \\
\hline Un- Sludge & 2.79 & 0.00 \\
\hline CB 10\% & 1.15 & 0.00 \\
\hline CB 20\% & 3.47 & 0.52 \\
\hline FO 10\% & 2.52 & 1.27 \\
\hline FO 20\% & 1.63 & 1.81 \\
\hline Si 10\% & 1.32 & 1.56 \\
\hline Si 20\% & 0.42 & 2.05 \\
\hline FO + CB & 0.00 & 1.88 \\
\hline Si + CB & 0.00 & 1.69 \\
\hline Si + FO & 0.00 & 1.59 \\
\hline LSD $\mathbf{0 . 0 5}$ & 0.10 & 0.07 \\
\hline
\end{tabular}

Very high Ni contents were recorded for the plants grown on these treatments as it is shown in Table (4). Treated sludge materials had different effects on the extractable Ni depending upon the type and the level of the stabilizing material, the application time and plant species. These results may need more analysis about the $\mathrm{Ni}$ forms and their contents of the soil and treatedsludge.

\section{References}

Abou-Seeda, M., A.M. Zaghloul and A. AbdEl-Galil. (2005). The role of cement dust in chemical remediation of the sludge treated soil. As- siut Univ. Bull. Environ. Res. 8: 89- 107.

Alcantara, S., D.V.Pérez, R.A. Almeida, G.M. Silva, J.C. Polidoro, Bettiol. (2009). Chemical changes and heavy metal partitioning in an W. oxisol cultivated with maize (Zea mays L.) after 5 years disposal of a domestic and an Industrial sewage sludge. Water, Air, and Soil Pollution 203, 3-16.

Amin, A.A. (2013). Evaluation of using certain industrial wastes in the reclamation and remediation of some soils. Ph.D. Thesis, Fac. Agric., Assiut Univ., Egypt. 
Angın, İ. and A.V. Yağanoğlu. (2009). Application of sewage sludge as a soil physical and chemical amendment. Ekoloji 19(73), 39-47.

Boland, N.S., R. Naidu, M.A.R. Khan and R.W. Tillman. (1999). The effect of anion sorption on sorption and leaching of cadmium. Australian J. of Soil Research 37: 445460.

DeVries, M. P. C. and K.G. Tiller. (1978). Sewage sludge as a soil amendment, with Special References to $\mathrm{Cd}, \mathrm{Cu}, \mathrm{Mn}$. $\mathrm{Ni}, \mathrm{Pb}$, and $\mathrm{Zn}$-Comparison of results from experiments conducted inside and outside a glasshouse." Environmental Pollution 16, pp 231- 40.

Diacono, M and F.Montemurro. (2010). Long-term effects of organic amendments on soil fertility. A review. Agron Sustainable Dev. 30(2):401-422.

Emmerich, W.E., L.J. Lund, A.L. Page and A.C. Chang. (1982). Movement of heavy metals in sewage sludge- treated soils. J. Environ. Qual. 11: 174- 178.

Fenglian, F. and Q. Wang. (2011). Removal of heavy metal ions from wastewaters: A review. Journal of Environmental Management.92: 407- 418.

Freed, R. D. (1992). MSTAT-C Software Program (Version 2.10). Crop and Soil Sciences Department, Michigan State University, USA.

Gomah H.H. (2015). In-Situ Remediation of Heavy Metals in Sewage Sludge Using Some Pesticides and Inorganic Amendments. Egypt J. Soil Sci. 55(4): 453-462.

Gomah, H.H. and H.A. Ezzeldin. (2003). Contamination of soils and some vegetable crops with heavy metals induced by applying some pesticides. Assiut J. Agric. Sci. 34 (6): 13- 31
Gomez K.A. and A.A. Gomez. (1984). Statistical Procedures for Agricultural Research. John Wiley \& Sons, New York.

Jackson, M. L. (1973). Soil chemical analysis. Constable and Co. Ltd., London, UK.

Jiang Y., Q.Geo, H. Yu, Y.Chenand F.Deng. (2007). Intensively competitive adsorption for heavy metal ions by PAMAM-SBA- 15 and EDTA-PAMAM-SBA-15 inorganic- organic hybrid materials. Micropor.Mesopor.Mater.103: 316- 324.

K. Weggler, M. J. McLaughlin and R. D. Graham.(2004). Effect of Chloride in Soil Solution on the Plant Availability of Biosolid-Borne Cadmium. Journal of Environmental Quality, Vol. 33, No. 2, pp. 496-504.

Kigel, M.Y., J.F. Shultis, E.S. Goldman and M.K. Demytrk. (1994). Method of detoxification and stabilization of soils contaminated with chromium ore waste. Patent and Trademark Office, United States Department of Commerce, Washington DC, USA, Patent No: 5, 304, 710 .

Martin, T.A. and M.V. Ruby. (2004). Review of in-situ remediation technologies for lead, zinc and cadmium in soil. Remediation 14 (3): 35- 53.

Paljevac, M., M.Primozic, M.Habulin, Z. Novak and Z.Knez. (2007). Hydrolysis of carboxymethyl cellulose catalyzed by cellulose immobilized on silica gel at low and high pressures. J. Super. Fluid. 43: 74- 80.

Parkinson, J. A. and S. E. Allen. (1975). A wet oxidation process suitable for the determination of nitrogen and mineral nutrients in biological material. Communications in Soil 
Science and Plant Analysis 6: 111.

Petersen, S.O., K.Henriksen, G.K Mortensen, P.H. Krogh, K.K. Brandt, J. Sorensen, T. Madsen, J. Petersen, C.Grøn. (2003). Recycling of sewage sludge and household compost to arable land: fate and effects of organic contaminants, and impact on soil fertility. Soil \& Tillage Research 72, 139152.

Repo, E., J.K. Warchol, A.Bhatnagar and M.Sillanpaa. (2011). Heavy metals adsorption by novel EDTAmodified chitosan- silica hybrid materials (2011). J. Colloid. Interface Sci. 358 (1): 261 - 267.

S. V. Mattigod and A. L. Page.(1983). Assessment of metal pollution in soil. Applied Environmental Geochemistry, pp. 355-394, Academic Press, London, UK.

Sen, T.K., S.P. Mahajan and K.C. Khilar. (2002). Adsorption of $\mathrm{Cu}^{2+}$ and $\mathrm{Ni}^{2+}$ on iron oxide and kaolin and its importance on $\mathrm{Ni}^{2+}$ transport in porous media. Colloids and surfaces A. physicochem. Eng. Aspects. 211: 91- 102. Society of America Proceedings 32, 3e 546.

Sterritt, R. M. and J. N. Lester. (1980). Concentrations of heavy metals in forty sewage sludges in England. Water Air and Soil Pollution 14, 125-131.

Sulek, M., M.Drolenik, M.Habulin and Z. Knez. (2010). Surface functionalization of silica coated magnetic nanoparticles for covalent attachment of cholesterol oxides. J. Magn. Magn. Mater. 322: 179185.

Udeigwe, T.K., P.N. Eze, J.M. Teboh and M.H. Stietiya. (2011). Application, chemistry and environmental implications of contaminant-immobilization amendments on agricultural soil and water qual- ity. Environ international. 37 (1): 258- 267.

Waseem, M., S.Mustafa, A.Naeem, K.H. Shahand I.Shah.(2011). Mechanism of Cd (II) sorption on silica synthesized by sol- gel method. National Center Chemical Engineering Journal. 169:78- 83.

Wear, J.I., C.E. Evans. (1968). Relationship of zinc uptake by corn and sorghum to soil zinc measured by three extractants. Soil Science Society of America Proceedings 32, $3 \mathrm{e} 546$.

Wild, S.R. and K.C. Jones. (1991). Organic contaminants in wastewaters and sewage sludges: Transfer to the environment following disposal. In: Jones KC (ed), Organic Contaminants in the Environment -Environmental pathways \& Effects. Elsevier, London, pp 133158.

Xu, P., G.M. Zeng, D.L. Huang, C.L. Feng, S.Hu, M.H. Zhao, C.Lat, Z.Wet, C.Huang, G.X. Xie and Z.F. Liu. 2012. Use of iron oxide nanomaterials in wastewater treatment a review. Sci. Total Environ. 424: 1- 10.

Yilmaz, D.D. and A.Temizgul. (2012). Assessment of arsenic and selenium concentration with chlorophyll contents of sugar beet (Beta vulgaris var. saccharifera) and wheat (Triticumaestivum) exposed to municipal sewage sludge doses. Water Air Soil Pollution, 223, pp 3057-3066.

Yuan, P., M. Fan, D.Yang, H. He, D. Liu, A. Yuan, J.X. Zhu and T.H. Chen.(2009). Montimorillonitesupported magnetite nanoparticles for the removal of hexavalent chromium (Cr VI) from aqueous solutions. J. Hazard. Mater.166: 821- 829 . 
أستخدام الحماة المعاملة ببعض مثبتات النيكل فى خفض تيسره فى التربة و امتصاصه بالنباتات

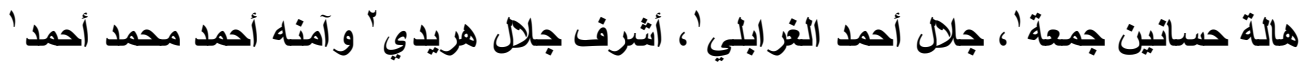

$$
\begin{aligned}
& \text { 'قسم الأر اضي و المباه ـ كلية الزر اعة - جامعة أسيوط }
\end{aligned}
$$

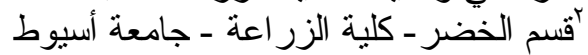

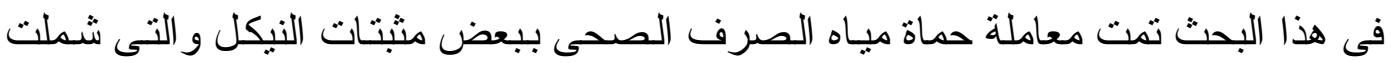

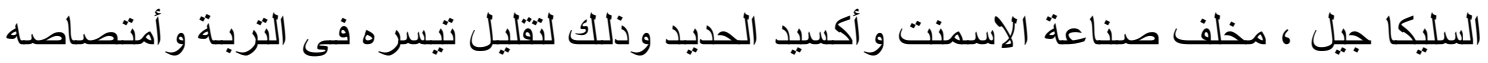

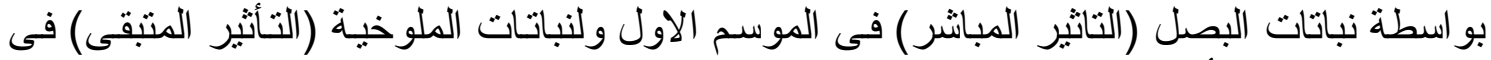

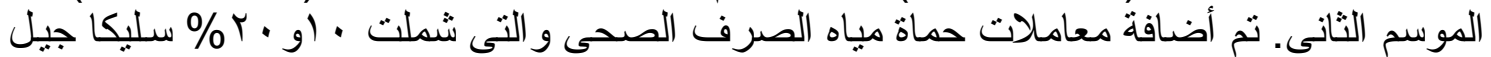

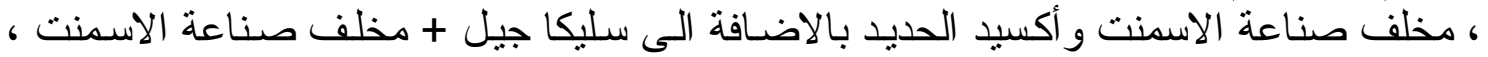

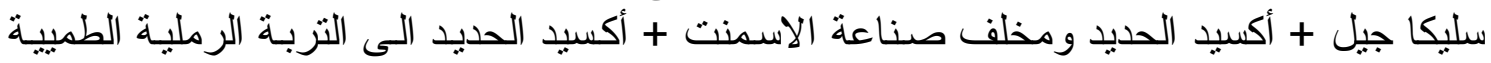

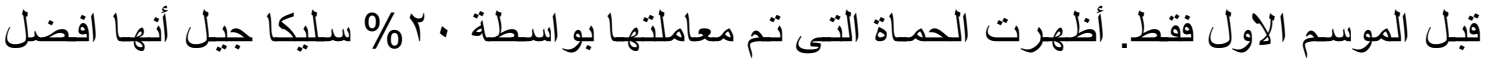

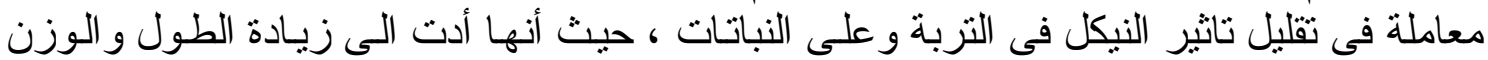

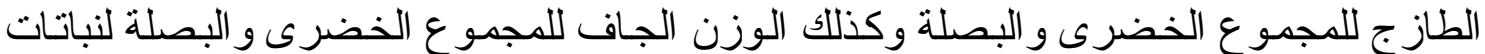

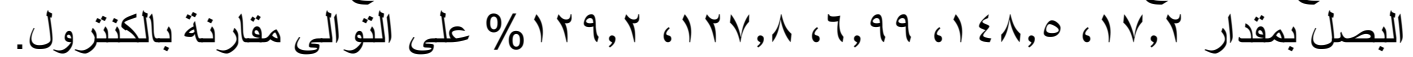

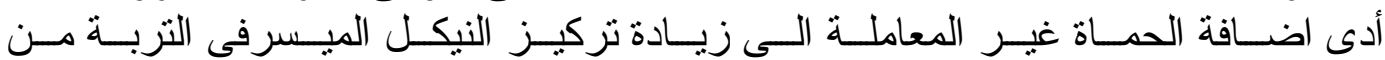

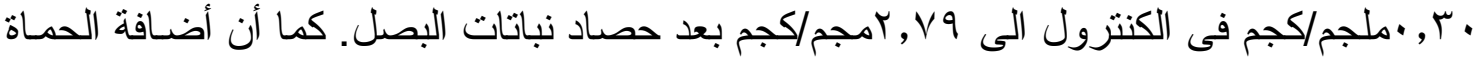

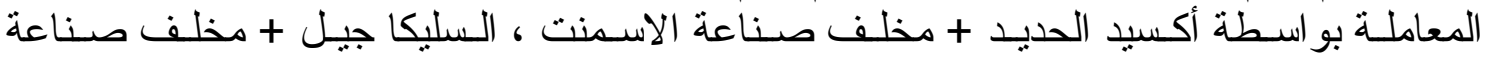

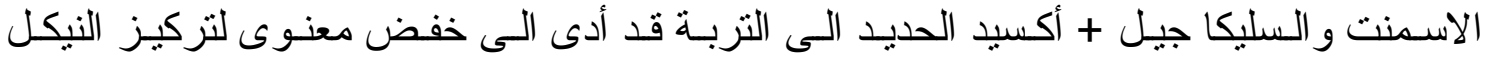

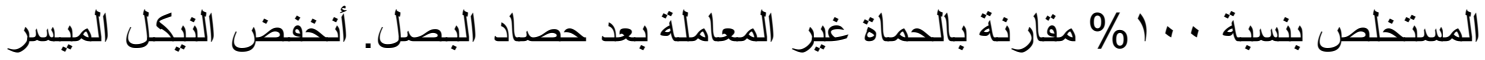

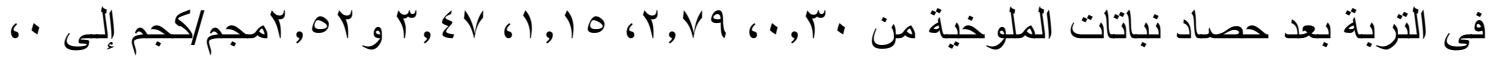

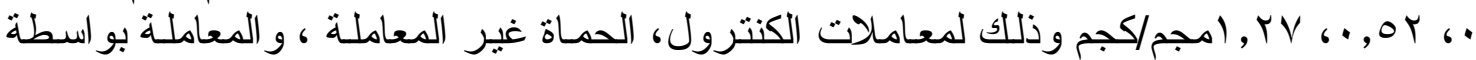

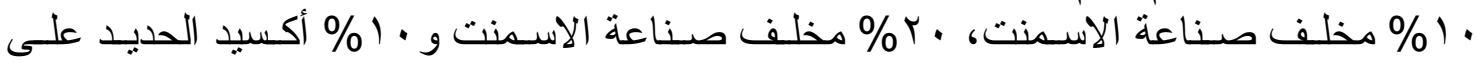

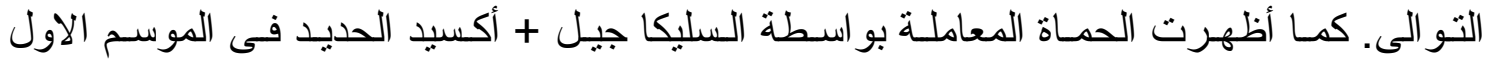

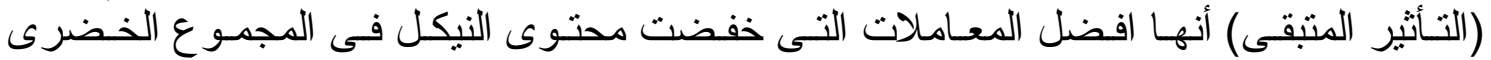

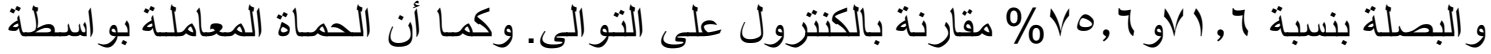

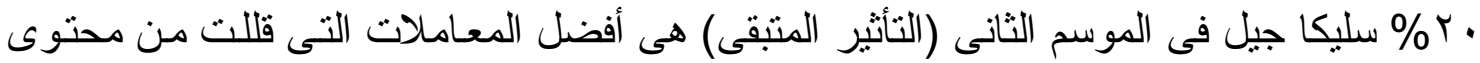

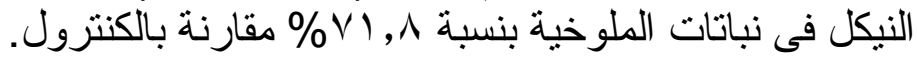

